\title{
Fixation-off sensitivity in focal epilepsy due to posterior quadrantic dysplasia
}

Eric P. Nagele, DO, Camilo A. Gutierrez, MD, Elsie Achieng, MD, and Jennifer L. Hopp, MD

Neurology ${ }^{\circledR}$ 2020;95:597-598. doi:10.1212/WNL.0000000000010621

\author{
Correspondence \\ Dr. Nagele \\ ericnagele@gmail.com
}

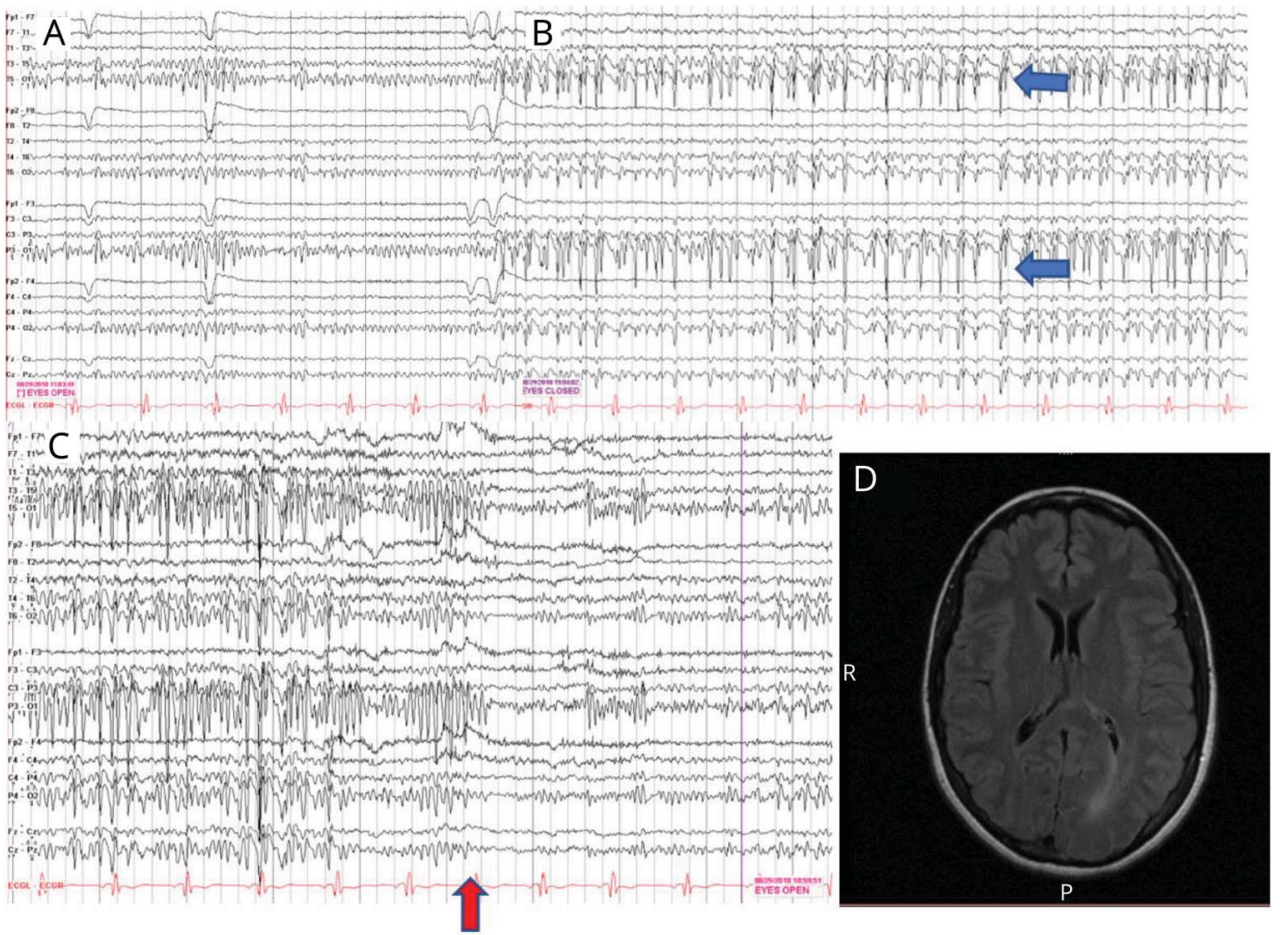

(A) An EEG in longitudinal bipolar montage reveals normal background frequencies with eyes open. (B) Eye closure induces left occipital spike discharges (blue arrows). (C) The left occipital spike discharges stop with eye opening (red arrow). (D) Brain MRI (axial fluid-attenuated inversion recovery) reveals localized left occipital posterior quadrantic dysplasia (hemi-hemimegalencephaly).

A 38-year-old woman with localized left occipital posterior quadrantic dysplasia complained of seizures described as "flashing lights" and confusion with rare convulsions. These were often induced by changes in lighting. EEG revealed left occipital spike discharges precipitated by eye closure (figure). Fixation-off sensitivity (FOS) is an uncommon phenomenon characterized by epileptiform discharges induced by elimination of central vision or fixation. FOS is most often associated with lesional epilepsy in adults, including focal cortical dysplasia, occipital calcifications in celiac disease, and parietal-occipital stroke. ${ }^{1}$ The proposed mechanism includes cortical hyperexcitability involving magnocellular and parvocellular pathways, alpha-rhythm generators, or defective glutaminergic and GABAergic pathways. ${ }^{2}$

\section{Study funding}

No targeted funding.

From the Department of Neurology (E.P.N., J.L.H.), University of Maryland School of Medicine, Baltimore; and Riverside Neurology Specialists (C.A.G., E.A.), Newport News, VA. Go to Neurology.org/N for full disclosures. Funding information and disclosures deemed relevant by the authors, if any, are provided at the end of the article. 


\section{Disclosure}

The authors report no disclosures relevant to the manuscript. Go to Neurology.org/N for full disclosures.

\begin{tabular}{lll}
\hline Appendix & Authors & \\
\hline Name & Location & Contribution \\
\hline Eric P. & $\begin{array}{l}\text { University of Maryland } \\
\text { Nagele, Do }\end{array}$ & $\begin{array}{l}\text { Sesign and } \\
\text { conceptualization, drafting } \\
\text { Baltimore }\end{array}$ \\
& $\begin{array}{l}\text { and revision of manuscript } \\
\text { for intellectual content }\end{array}$ \\
\hline $\begin{array}{l}\text { Camilo A. } \\
\text { Gutierrez, }\end{array}$ & $\begin{array}{l}\text { University of Maryland } \\
\text { SD }\end{array}$ & $\begin{array}{l}\text { Drafting and revision of } \\
\text { manuscript for intellectual } \\
\text { content }\end{array}$ \\
\hline
\end{tabular}

\begin{tabular}{|c|c|c|}
\hline Name & Location & Contribution \\
\hline $\begin{array}{l}\text { Elsie } \\
\text { Achieng, } \\
\text { MD }\end{array}$ & $\begin{array}{l}\text { Riverside Neurology } \\
\text { Specialists, Newport } \\
\text { News, VA }\end{array}$ & $\begin{array}{l}\text { Drafting and revision of } \\
\text { manuscript for intellectual } \\
\text { content }\end{array}$ \\
\hline $\begin{array}{l}\text { Jennifer L. } \\
\text { Hopp, MD }\end{array}$ & $\begin{array}{l}\text { University of Maryland } \\
\text { School of Medicine, } \\
\text { Baltimore }\end{array}$ & $\begin{array}{l}\text { Design and } \\
\text { conceptualization, drafting } \\
\text { and revision of manuscript } \\
\text { for intellectual content }\end{array}$ \\
\hline
\end{tabular}

\section{References}

1. Tirol FG. New-onset fixation-off sensitivity or scotosensitivity in an adult male after bilateral embolic strokes of the parietal and occipital regions. Clin EEG Neurosci 2017;48:413-416.

2. Fattouch J, Casciato S, Lapenta L, et al. The spectrum of epileptic syndromes with fixation off sensitivity persisting in adult life. Epilepsia 2013;54:59-65.

\section{Did You Know...}

... you can browse by subspecialty topics on Neurology.org?

Go to: Neurology.org and click on "Topics" in the top navigation bar.

\section{The AAN is at Your Side}

When you're in the office, the AAN is at your side. The AAN is your \#1 resource to support you and your care team. Whether it's resources to help you and your staff provide the best care for your patients, ensure proper reimbursement, or maximize practice performance, the AAN is at your side. Access these resources today at AAN.com/view/practiceresources.

\section{Neurology ${ }^{\circledR}$ Online CME Program}

Earn CME while reading Neurology. This program is available only to online Neurology subscribers. Read the articles marked CME, go to Neurology.org, and click on CME. This will provide all of the information necessary to get started. The American Academy of Neurology (AAN) is accredited by the Accreditation Council for Continuing Medical Education (ACCME) to sponsor continuing medical education for physicians. Neurology is planned and produced in accordance with the ACCME Essentials. For more information, contact AAN Member Services at 800-879-1960. 


\section{Neurology}

Fixation-off sensitivity in focal epilepsy due to posterior quadrantic dysplasia Eric P. Nagele, Camilo A. Gutierrez, Elsie Achieng, et al.

Neurology 2020;95;597-598 Published Online before print August 11, 2020

DOI 10.1212/WNL.0000000000010621

This information is current as of August 11, 2020

\section{Updated Information \&} Services

\section{References}

Subspecialty Collections

\section{Permissions \& Licensing}

\section{Reprints}

including high resolution figures, can be found at: http://n.neurology.org/content/95/13/597.full

This article cites 2 articles, 0 of which you can access for free at: http://n.neurology.org/content/95/13/597.full\#ref-list-1

This article, along with others on similar topics, appears in the following collection(s):

All Epilepsy/Seizures

http://n.neurology.org/cgi/collection/all_epilepsy_seizures Cortical dysplasia

http://n.neurology.org/cgi/collection/cortical_dysplasia

EEG

http://n.neurology.org/cgi/collection/eeg_

EEG; see Epilepsy/Seizures

http://n.neurology.org/cgi/collection/eeg_see_epilepsy-seizures

MRI

http://n.neurology.org/cgi/collection/mri

Information about reproducing this article in parts (figures,tables) or in its entirety can be found online at:

http://www.neurology.org/about/about_the_journal\#permissions

Information about ordering reprints can be found online:

http://n.neurology.org/subscribers/advertise

Neurology ${ }^{\circledR}$ is the official journal of the American Academy of Neurology. Published continuously since 1951, it is now a weekly with 48 issues per year. Copyright () 2020 American Academy of Neurology. All rights reserved. Print ISSN: 0028-3878. Online ISSN: 1526-632X.

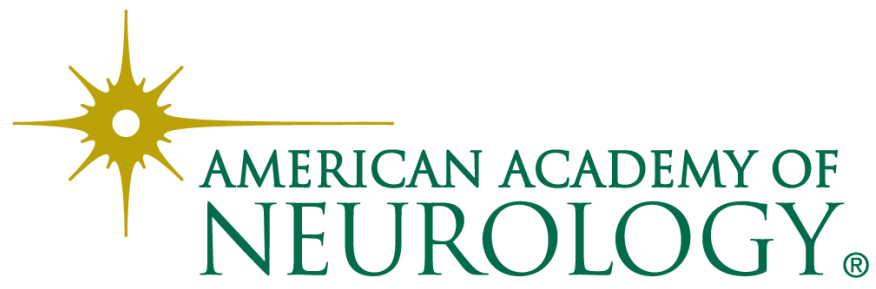

